\title{
COMPETENCE MATRICES AS AN INSTRUMENT FOR SCHEDULING PRODUCTION AND PLANNING HUMAN RESOURCE TRAINING NEEDS
}

\author{
Elżbieta MILEWSKA ${ }^{1 *}$, Anna GEMBALSKA-KWIECIEŃ ${ }^{2}$ \\ ${ }^{1}$ Silesian University of Technology, Faculty of Organization and Management, Zabrze; \\ Elzbieta.Milewska@polsl.pl, ORCID: 0000-0001-8053-4333 \\ ${ }^{2}$ Silesian University of Technology, Faculty of Organization and Management, Zabrze; \\ Anna.Gembalska-Kwiecien @ polsl.pl, ORCID: 0000-0001-9275-0447 \\ * Correspondence author
}

Purpose: The main purpose of this study was to present the possibilities of using the competence matrix in the prioritizing of manufacturing activities.

Design/methodology/approach: The article discusses one of the enterprise's human resource management instruments, which are competence matrices. Competence development model of enterprise was presented and model of using technological competences was discussed.

Findings: The way of using competence matrices, as a tool to support task scheduling that is carried out by direct production employees in the area of discrete processes, was presented. The author showed, that competence matrices can enable the identification of competence gaps and thus be a tool for planning the training needs of employees, recruitment and selection of employees, making decisions about transfers and building a remuneration system.

Research limitations/implications: An important condition for the successful implementation of solutions based on competence matrices is the correct determination of the level of required and expected technological competence and prior declaration of the list of technological operations.

Practical implications: The solution described above, consisting in the use of technological competence matrices in the area of production planning, has been used in the calculation algorithms of the IPOsystem ${ }^{\mathrm{TM}}$ application. It is a product of the Polish company UiBS Teamwork Sp. z o.o.

Originality/value: The use of competence matrices in prioritizing production tasks is undoubtedly a new issue. It is an indicator of the level of organization's maturity, which results from the need to adapt production enterprises to changing environmental conditions.

Keywords: competences, qualifications, human resources management, task prioritizing, technological operations.

Category of the paper: Case study. 


\section{Introduction}

Human capital is a key element of the enterprise's value. In a knowledge-based economy, combining the skills and experience of employees, as well as their involvement in acquiring competences, creates not only a factor shaping the culture of the organization, but also allows to confirm the effectiveness of the implementation of entrusted tasks (Linowska, 2010). The employee competence management system should be based on objective and unambiguous principles. Competence matrices are one of the enterprise's human resources management instruments. They can be a tool for:

- recruitment and selection of employees,

- planning their training needs,

- making decisions about promotions, transfers and dismissals,

- and building a remuneration system.

An innovative solution, presented in the article, is to discuss how to use competence matrices as a tool to support task scheduling that is carried out by direct production employees in the area of discrete processes. Competence matrices are also used in prioritizing the manufacturing activities. The implementation of this objective was made possible through own research carried out in selected manufacturing companies.

\section{The concept of competence and qualifications}

In the literature on human resource management, the concept of qualifications and competences is often used interchangeably. However, it is appropriate to clarify the scope of both concepts. Most frequently, the concept of qualification refers to the quality of the employee's preparation for the job. In other words, it indicates the existence of a certain potential, shaped in accordance with accepted community standards. According to G.S. Becker (Becker, 2007), qualifications are defined as a specific training, that benefits the employer, which may mean the employer bearing investments in the preparation of employee's efficiency.

The result of the diversity of labor standards was the separation of groups called professions. Along with the increase in specialization, the problem of adjusting the scope of work to the capabilities of the contractor was noticed (Orczyk, 2009). According to the author of this article, professional qualifications are a certain recognized potential, constituting an individual system of knowledge, skills and attitudes, conditioning the performance of specific professional tasks. It is shaped by the configuration of factors, which includes: level of education, professional experience, as well as mental and physical features. It is also related to the investments borne 
for its creation and functioning. However, the assessment of the potential changes depending on the demand or the degree of use of qualifications.

The significance of the scope of identification of required skills and the way they are acquired has become a source of increase in importance of the term "competences". Initially, competences were of a formal nature. They indicated the scope of authority to make decisions or carry out specific tasks, performed in accordance with the chosen procedure. Over time, the scope of this concept began to change. In McClelland's (McClelland, 1973), Boyatzisa's (Boyatzis, 1982) and Spencer's view (Spencer, L.M., and Spencer, S.M., 1993), competences consist of personality traits needed by the employee to properly perform work. The environment is important in demonstrating competences. It is described through the economic, political, social, religious and environmental aspects. The need to adapt to specific working conditions means that competences are revealed when performing specific work. They often confirm the qualifications acquired by the employee. Competences prove the ability to use their knowledge and traits. They determine the possibility of intentional undertaking of actions and their effective implementation, while maintaining responsibility, accepted standards or in accordance with the previously concluded agreement. In other words, the scope and use of competences determine the effects at work, while professional work forces constant update of qualifications.

Both qualifications and competences are undergoing transformation. The changes not only result from the change in working conditions, but also due to the phase of life, family and health situation of the employee. The uncertainty of the environment and the way the enterprise functions are of particular importance. It leads to changes in the relationship between qualifications and competences of employees. The conducted research (Lopez-Casanovas, et al., 2005; Pennings, et al., 2007) indicated that both human capital value estimated in relation to individual persons and human communities are subject to these changes. There is also a noticeable increase in awareness of the importance of assessing human capital in building a company's development strategy. It mainly results from the increase in the value of work and leads to an attempt to shape human capital.

Because achieving business objectives of an organization is dependent on possessing competences, while compliance with procedures is determined by acquired qualifications, therefore, a symbiosis in shaping and using human capital is not only advisable, but rather necessary. 


\section{Competence model - expectation profile}

For the purposes of this study, it has been assumed that competences are a set, owned by the employee, of (Figure 1):

- knowledge, i.e. the scope of acquired entitlements to carry out tasks;

- skills, i.e. the practical abilities of the employee;

- and attitudes, i.e. mindset and motivation for undertaken actions.

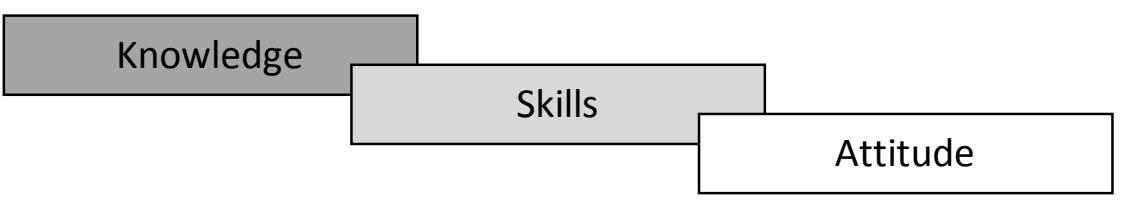

Figure 1. Components of competence. Own elaboration.

The enterprise's competences are determined, among others, by the nature of manufacturing activities, the company's organizational structure, the scope of employee responsibility and social culture, which is shaped by the attitude of colleagues, superiors and subordinates (LopezCasanovas et al., 2005; Pennings et al., 2007).

Competence modeling is a set of activities aimed at creating a model, bringing together a set of key employee competences that are necessary for the effective performance of tasks at a selected work position (Juchnowicz, and Sienkiewicz, 2006) or performing a specific organizational role in the enterprise Their selection is made based on:

- legal acts regulating the functioning of an economic entity,

- business goals of the enterprise,

- required flexibility and employee substitutability

- and conditions limiting the implementation of service or manufacturing actions.

In the simplest terms, the competence model resembles a table, in which rows represent organizational roles or, alternatively, work positions, while columns present competences. The set of competences is often divided into groups. The model does not take into account all personnel abilities, but only those that are significant from the perspective of the team's functionning and implementation of tasks.

In order to determine the skill set level of individual competences, expected by the organization, necessary for the implementation of the tasks entrusted to employees, an indicator of the level of proficiency or/and validity of competences is used. The value of the indicator is entered into the table cell located at the intersection of the organizational role with the competence. Most often, the indicator grade's value gains a numerical amount. The grading scale is adapted to the enterprise requirements. Theoretically, there is no limit to the range of the grading scale, but in practice, a maximum of several levels is used. Often, in order to 
increase the readability of the graphic form of the model, the digits are replaced with colours or, alternatively, with percentages (Table 1).

\section{Table 1.}

Competence model

\begin{tabular}{|c|c|c|c|c|}
\hline & 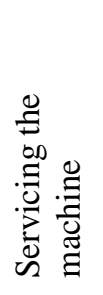 & 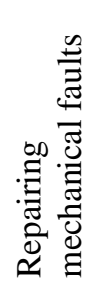 & 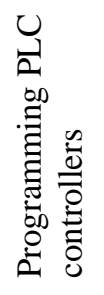 & 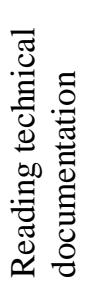 \\
\hline $\begin{array}{l}\text { Work position / } \\
\text { organizational role } 1\end{array}$ & - & 0 & - & • \\
\hline $\begin{array}{l}\text { Work position / } \\
\text { organizational role } 2\end{array}$ & $\bigcirc$ & 0 & • & • \\
\hline $\begin{array}{l}\text { Work position / } \\
\text { organizational role } 3\end{array}$ & 0 & 0 & - & \\
\hline
\end{tabular}

\author{
KEY \\ - Expert \\ - Independent employee \\ - Satisfactory skills \\ 0 - Training in progress \\ - Lack of skill set
}

Own elaboration.

The indicator value indicates the required level of predisposition of an employee occupying a specific position or performing a selected role in the organization, in terms of knowledge, skills and attitudes, to perform a task. Most often, the grade is based on behavioral and qualification criteria, and less often on effective ones. By adopting, for example, a five-point scale (0-4), the enterprise declares that, in order to act as a manager, it does not require an employee to have competence (grade: 0 ), the task may be carried out by an employee participating in the training (grade: 1) or, alternatively, task performance is conditional on satisfactory competence (grade: 2), appropriate / independent employee (grade: 3) or perfect/ the employee teaches others (grade: 4 ).

\section{Competence matrix - actual profile}

Employees' competences are valuable capital at the organization's disposal. Their proper identification plays a key role in improving the team's professional development. When measuring employee competences, the level of individual competence mastery by employees is assessed in relation to the requirements and expectations formulated in the organization in the form of position competence profiles. This process is called competence audit or balance of competences. Its main goal is to analyze competences available in the organization. The assessment of employees' competences can be made through various methods. There are three main groups among them: tests, interviews and surveys.

The most popular methods of diagnosing the state of employees' competences are tests (Emmons et al., 1986); Whiddett, and Hollyford, 2003). They measure the level of knowledge in a specific field and verify the ability to use knowledge in various situations. They are usually 
developed by specialists. Answers often take the form of multiple-choice, whose individual items describe situations specific to the position or organizational role.

Interviews with employees are a good complement to the data obtained using the test method (Dipboye et al. 2004). They take the form of a biographical, behavioural or situational interview. They focus on the individual's social and professional experiences and typical behaviours of the assessed person. They are to verify whether the assessed person was once in a situation characteristic of the chosen job and whether they demonstrated specific competences that allow them to properly perform the entrusted task. However, it should be remembered, that the material collected in the interview contains only the subjective statements of the respondents and, therefore, should not be used as the only tool for assessing employee competences.

Another method of measuring employee competences is the survey method. It involves collecting opinions about an employee from people who currently cooperate with him. The observed individual is assessed from different perspectives. The collected results are averaged and form the basis for issuing the final grade. Depending on the number of sources of information, the method takes the name: $180^{\circ}, 270^{\circ}, 360^{\circ}$ or $540^{\circ}$. The $180^{\circ}$ method involves the use of two sources of information. It consists in self-assessment and assessment made by a direct superior. In the case of the $270^{\circ}$ method, information about the competences of the assessed individual comes from their colleagues, superiors and subordinates, while customers are omitted. The $540^{\circ}$ method is the most extensive, which also takes into account the opinions of external customers and external suppliers. However, the $360^{\circ}$ method is most widely described in the literature (Filipowicz, 2004; Garavan et al., 1997; Hurley 1998; McCarthy, and Garavan, 2001; Smółka, 2008). It contains the grade given by subordinates, co-workers and clients. It should be noted that multi-source opinions ensure objectivity of the described methods, and feedback provided to the employee is undoubtedly an added value, due to the evaluation of competences.

The assessment of employee behaviour should relate to predefined expectations. If the employer's requirements are recorded in the competence model, then the employee's assessment should be made using this model.

In the competence matrix, in the place of organizational positions and roles, the names and surnames of employees included in the organization's team are entered. Then the table is supplemented with the value of indicators describing the professional predispositions that individual persons offer. Because the competence matrix is a set of cumulative totals, therefore, it is an excellent tool for finding and making comparisons and summaries of competences.

The competence matrix is a reference system used when comparing the expectations posed by company managers with their staff potential. The comparison enables the identification of competence gaps, planning the professional development paths of individual employees and determining their training needs. It is also used in monitoring the continuity of raising employee competences and the planned rotation of work, preparing replacements and elimination of 
irreplaceable employees. These activities contribute to ensuring continuity of economic processes and increase in production flexibility.

\section{Competence management}

The employee's professional development process should take place with the participation and co-decision of both the superior and the subordinate. The task of the supervisor is to inform about the possibilities of individual development, constant motivation of the employee and building their loyalty to the company and involvement in its activities. The employee, on the other hand, is obliged to engage in self-development, raise their qualifications and acquire new experiences. Only the simultaneous implementation of both of these recommendations: supervisor and subordinate, is the key to meeting both the employee's ambitions and the company's requirements.

The use of the competence matrix in the field of personnel policy ensures precision, purposefulness and coherence of undertaken operations. The matrix is particularly useful in large organizations, where, with regard to extensive organizational structures, problems may arise related to the efficient allocation of tasks to employees. Through the application of position specialization and the creation of competence lists, matrices allow employees to be replaced in teams with a significant number or large fluctuation (liquidity) of staff, which is undoubtedly a phenomenon inherent in the activities of each enterprise.

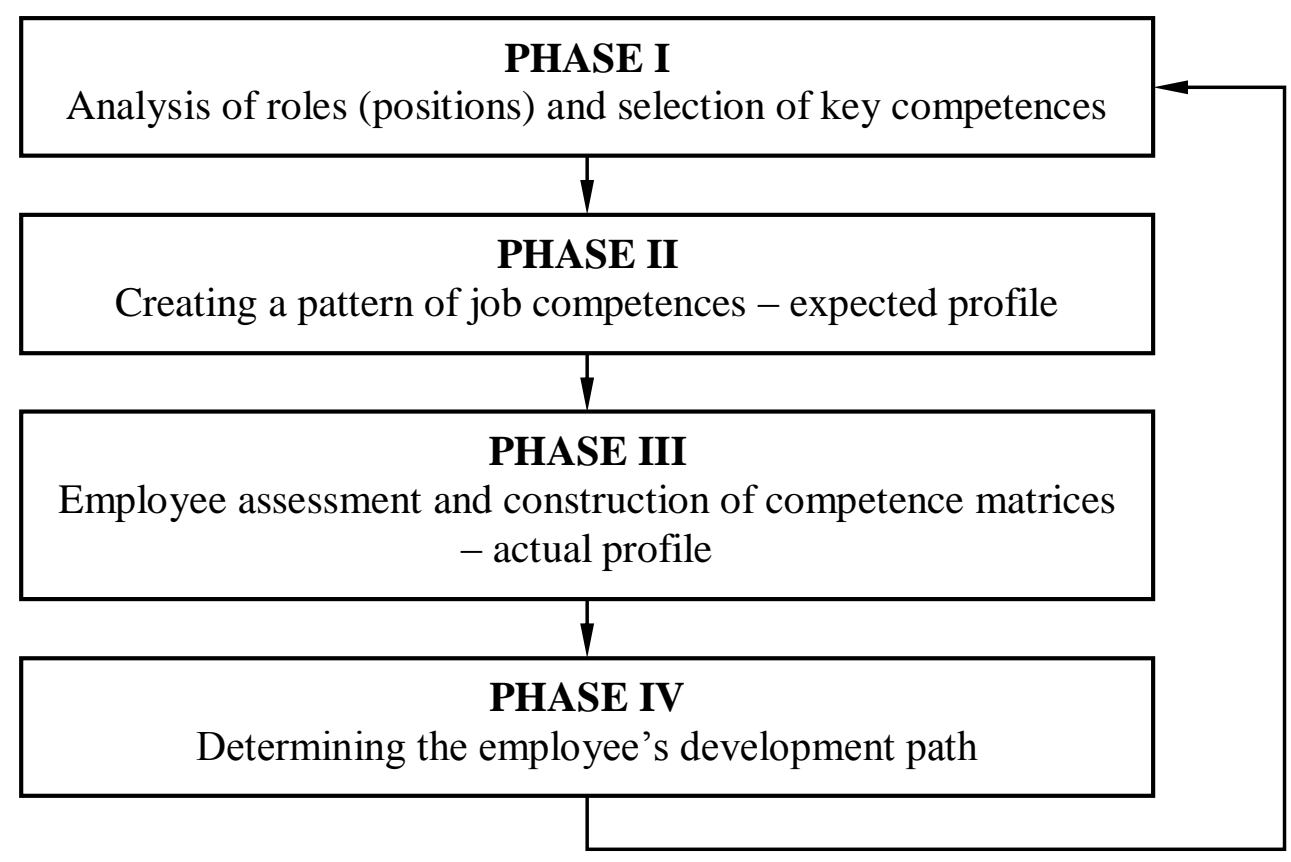

Figure 2. Competence development model of enterprise. Own elaboration. 
Improving the human resource management process, as well as increasing employee efficiency and satisfaction with work should be implemented continuously. The cyclical nature of activities associated with the adaptation of the enterprise to the changing conditions of conducting business and the desire to increase the efficiency of employee competence management is presented in the competence development model (Figure 2). It covers the implementation of the following employer activities:

- identifying the company's organizational roles (work positions) and key employee competences - phase I,

- creating the profile expected for positions by specifying the required level of competence of individual roles - phase II,

- creating an actual profile by examining the current level of employee competences phase III,

- comparing the actual profile with the expected one and determining the path to develop competences of individual specializations - phase IV.

Verification of the effectiveness of the actions undertaken is reflected in the employee's periodic assessment and is an inherent element of the described process.

\section{Competence structure of a production enterprise}

Disruptions occurring in the course of manufacturing activities often require immediate decision-making regarding changes in the production process. The causes of disruptions are, among others: machine faults, employee indisposition, late delivery of materials, product quality irregularities and others. The correct interpretation of signals received from the work environment and quick identification of the cause of disorders is the basis of the process of adaptation and elimination of deviations. However, undertaking coordination activities depends not only on the knowledge of cause and effect relationships of the process implementation, but also on having knowledge about the time availability and competence of the staff, as well as the level of technological advancement of the company's machine park.

Operational plans are the most vulnerable to change. They are corrected both in the area of resource allocation and quantitative material demand. It should be noted that the degree of flexibility of operational plans is primarily determined by the substitutability of resources. The search for an alternative contractor or even a replacement for a work position that will enable the same effect of production activities is subject to the temporary availability and specialization of compatible resources. The flexibility of the plans requires the manufacturer not only to undertake investment activities, including the expansion or modernization of the machine park to obtain alternative work positions, but also to conduct a competence-oriented personnel policy. An important issue for the company is stabilizing employee fluctuations and 
promoting niche competences. This policy, implemented through recruitment and professional development of employees, leads to complementarity of competences in the team and coherence of assessment criteria.

It is obvious, that organizing the work of direct production employees requires the identification of competences, including knowledge, skills and attitudes, necessary in conducting manufacturing activities and based on the implementation of operations or technological operations. The authors of this article called them technological competences. For a significant number of business entities, they form the basis for the development of company job description sheets.

A unique solution is the use of competence matrices as a tool that forms the basis of production scheduling. The criterion for matching the contractor and the work position to the requirements for operations or technological procedures, included in the technology production order, is technological competence.

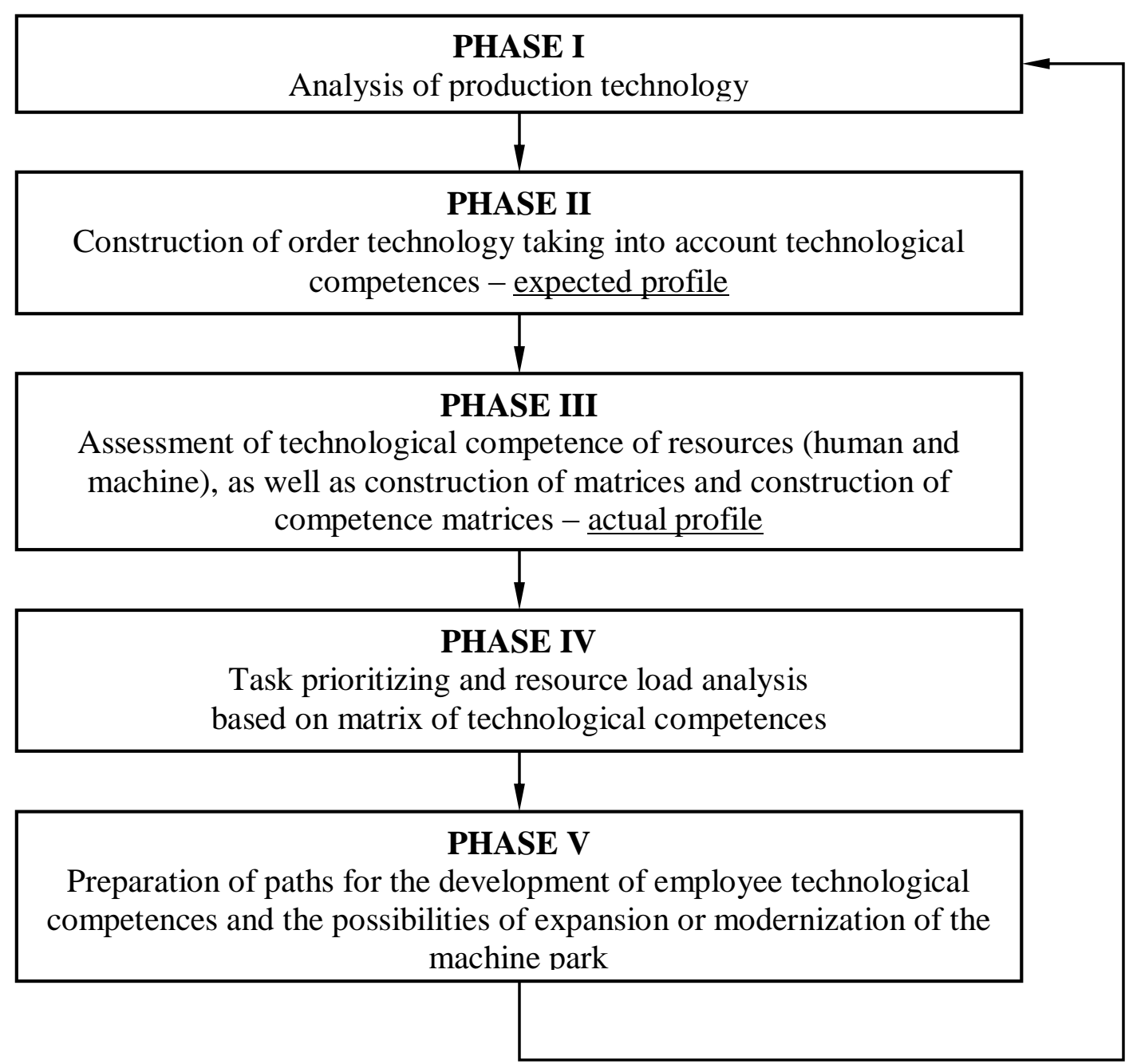

Figure 3. Model of using technological competences. Own elaboration. 
The basis for the creation of these technological competence matrices is the proper definition of the list of technological operations (phase I in Figure 3). They are understood as an activity performed by one employee (or alternatively a team) at one workstation. Identification of operations consists in analyzing the possibilities of using resources with regard to their substitutability. This means that the interchangeability of resources allocated to the task is taken into account, which should not cause differentiated production effects.

Task prioritizing also requires the creation of two matrices (phase II and phase III in Figure 3). The first matrix is the expected profile (phase II). It describes the imposed requirements of production technology. It contains a list of parameterized technological operations, for which the minimum level of proficiency in using the competence or the degree of adaptation of the resource to the implementation of entrusted tasks is determined.

The second type of matrices are actual profiles (phase III in Figure 3). They describe the competences that resources have at their disposal. At this stage of work, a separate matrix of technological competences is created for direct production employees and for work positions, which were separated within the company's machinery park. The matrix of technological competence of employees is a cross-list of names and surnames of persons (or registration numbers of employees who make up the team) with the list of technological operations. In the matrix created for the resources of the machine park, the list of persons is replaced by the list of work positions. The cells of the tables evaluate the adaptation of the resource to perform the selected technological operation.

The search for solutions, forming the production plan (phase IV in Figure 3) includes the allocation of resources, while meeting the criterion of their availability and compatibility of competences. Each of the solutions obligatorily refers to a pair of resources: machine and human. The temporary availability of the resource is read from the work time calendar of the unit. It records the periods of leave or employee indisposition or, alternatively, in the machine calendar - the time of planned renovation or maintenance. Competence compliance is determined by comparing the assessment of proficiency of competences held by resources (actual profile) with the competence requirements of the technological process (expected profile) (Milewska, and Gembalska-Kwiecień, 2018). The assessment of resource competence must be at least equal to the adopted requirements. It is obvious that obtaining the correct solutions is subject to taking into account other conditions limiting the course of production processes in production scheduling (Milewska, 2011a, 2011b, 2014a, 2014b, 2016, 2017).

Precise mapping in the competence matrices of technological conditions, as well as personal talents and predispositions is the basis for making decisions regarding the organization's business development strategy (phase $\mathrm{V}$ in Figure 3). Analysis of the load on individual resources allows for identification of bottlenecks, which are employee competences or directions of expansion sought for, or modernization of the machine park. 


\section{Application of technological competence matrix}

The solution described above, consisting in the use of technological competence matrices in the area of production planning, has been used in the calculation algorithms of the IPOsystem $^{\mathrm{TM}}$ application. It is a product of the Polish company UiBS Teamwork Sp. z o.o. The solution is based on the Microsoft SQL Server version: Express Edition, Standard Edition or Enterprise Edition. The functionality of the IPOsystem ${ }^{\mathrm{TM}}$ system includes planning, controlling and recording manufacturing activities. Data collected and processed by IPOsystem $^{\mathrm{TM}}$ descrybes both the workflow and the material flow (Milewska, and Skowron, 2018a, 2018b; Skowron, and Milewska, 2018). The process of creating plans is fully automated, periodically initiated and triggered after reaching the declared boundary conditions. Criteria for the implementation of the plan described by correlated coefficients of determination, which represent the relationship between the current course of manufacturing activities and the expected results, included in the previously generated production plan. Timeliness of production plans is ensured by successive registration of events. IPOsystem ${ }^{\mathrm{TM}}$ forces direct production employees to keep current records of the time when technological operations start and finish. Reporting and issuing an instruction to perform work for the operator takes place via the terminal. It recognizes the contractor by the RFID proximity identifier, working in the Unique $125 \mathrm{kHz}$ system.

\section{Conclusions}

Requirements for enterprises force us to look for better mechanisms guaranteeing efficiency and effectiveness in a dynamically changing environment. The authors of this article present a new view on the use of the potential inherent in the competences of human capital. They believe that it is the basis for flexible management of direct production employees. The key issue for the discussed solution seems to be the identification of the area of connections of three concepts: the conditions for the implementation of technological operations, employee qualifications and adaptation of workstations to work. The use of competence matrices in prioritizing production tasks is undoubtedly a new issue. It is an indicator of the level of organization's maturity, which results from the need to adapt production enterprises to changing environmental conditions. The implementation of competence matrices has created the possibility of a systematic and structured orientation on shaping the desired competences by the organization. It also contributed to the identification of competence gaps affecting the timely delivery of orders. It should also be noted, that the use of competence matrices in business practice is not limited to large enterprises operating in selected industries. It is a tool that can 
be successfully used in any enterprise and industry. However, an important condition for the successful implementation of solutions based on competence matrices is the correct determination of the level of required and expected competence.

\section{Acknowledgements}

This article was created as part of statutory work 13/010/BK_19/0034 conducted at the Institute of Economics and Informatics at the Faculty of Organisation and Management of the Silesian University of Technology.

\section{References}

1. Becker, G.S. (2007). Economic Theory. New York: Routledge. https://doi.org/10.4324/9781351327688.

2. Boyatzis, R.E. (1982). The Competent Manager: A Model of Effective Performance. New York: John Wiley \& Sons.

3. Dipboye, R.L., Wooten, K., and Halverson, S.K. (2004). Behavioral and situational interviews. In: J.C. Thomas (Ed.), Comprehensive handbook of psychological assessment. Industrial and organizational assessment, 4 (pp. 297-316). Hoboken, NJ, US: John Wiley \& Sons Inc.

4. Emmons, R.A., Diener, E., and Larsen, R.J. (1986). Choice and avoidance of everyday situations and affect congruence: Two models of reciprocal interactionism. Journal of Personality and Social Psychology, 51(4), pp. 815-826. http://dx.doi.org/ 10.1037/00223514.51.4.815.

5. Filipowicz, G. (2004). Zarzadzanie kompetencjami zawodowymi. Warszawa: PWE.

6. Garavan, T.N., Morley, M., and Flynn, M. (1997). 360 degree feedback: Its role in employee development. Journal of Management Development, 16(2), pp. 134-147. http://dx.doi.org/10.1108/02621719710164300.

7. Hurley, S. (1998). Application of team-based $360^{\circ}$ feedback systems. Team Performance Management, 4(5), pp. 202-210. https://doi.org/10.1108/13527599810234164.

8. Juchnowicz M., and Sienkiewicz, Ł. (2006). Jak oceniać pracę? Wartość stanowisk $i$ kompetencji. Warszawa: Difin.

9. Linowska, A. (2010). Zarządzanie wartością kapitału ludzkiego w przedsiębiorstwie. Zeszyty Naukowe Uniwersytetu Szczecińskiego, 34, pp. 207-223. 
10. Lopez-Casanovas, G., Rivera, B., and Currais, L. (2005). (Eds.), Health and Economic Growth: Findings and Policy Implications, 1. Cambridge: The MIT Press.

11. McCarthy, A., and Garavan, T. (2001). $360^{\circ}$ feedback process: performance, improvement and employee career development. Journal of European Industrial Training, 25(1), pp. 5-32. https://doi.org/10.1108/03090590110380614.

12. McClelland, D.C. (1973). Testing for competence rather than "intelligence". American Psychologist, 28, pp. 1-14.

13. Milewska, E. (2011a). Wykorzystanie narzędzi informatycznych w procesie sterowania strumieniem przepływu materiałowego. Mechanik, 7(84), CD, pp. 575-582.

14. Milewska, E. (2011b). Zintegrowane systemy informatyczne wspomagające zarządzanie zdolnościami produkcyjnymi. Studia i Materiaty Polskiego Stowarzyszenia Zarzadzania Wiedza, 40, pp. 263-271.

15. Milewska, E. (2014a). Aspekty techniczne i organizacyjne wdrożenia systemu informatycznego wspomagającego planowanie produkcji. Systemy Wspomagania w Inżynierii Produkcji, 2(8)/2014/13, pp. 142-152.

16. Milewska, E. (2014b). Wykorzystanie wiedzy technologicznej w procesie sterowania przepływem produkcji. In: R. Knosala (Ed.), Innowacje $w$ zarzadzaniu i inżynierii produkcji. T. 1 (pp. 604-613). Opole: Oficyna Wydaw. Polskiego Towarzystwa Zarządzania Produkcją.

17. Milewska, E. (2016). Wdrożenie hybrydowej metody sterowania produkcją dyskretną. In: R. Knosala (Ed.), Innowacje w zarządzaniu i inżynierii produkcji. T. 1 (pp. 759-767). Opole: Oficyna Wydaw. Polskiego Towarzystwa Zarządzania Produkcją.

18. Milewska, E. (2017). IT systems supporting the management of production capacity introduction. Management Systems in Production Engineering, 1(25), pp. 60-67. doi: 10.1515/mspe-2017-0009.

19. Milewska, E., and Gembalska-Kwiecień, A. (2018). Selected aspects of human resources management based on competence matrix. 5th International Multidisciplinary Scientific Conference on Social Sciences and Arts. SGEM 2018 Conference proceedings. Book 1, Vol. 5, pp. 861-866. doi: 10.5593/sgemsocial2018/1.5/S05.107.

20. Milewska, E., and Skowron, B. (2018a). Use of IT technologies in the calculation of the technological production cost conducted - a case study. In: A. Albrychiewicz-Słocińska, A. Czarnecka, and A. Dunay (Eds.), Challenges of management in modern organizations (pp. 188-196). Gödöllő.

21. Milewska, E., and Skowron, B. (2018b). Use of IT technologies in the management of production process quality. MATEC Web of Conferences, 183, 03012. doi: 10.1051/matecconf/201818303012.

22. Orczyk, J. (2009). Wokół pojęć kwalifikacji i kompetencji. Zarządzanie Zasobami Ludzkimi, 3-4, pp. 19-32. 
23. Pennings, J.M., Lee, K., and van Witteloostuijn, A. (2007). Human capital, social capital, and firm dissolution. In: J.M. Pennings, and F.C. Wezel (Eds.), Human Capital, Inter-Firm Mobility and Organizational Evolution (pp. 81-110). Cheltenham: Edward Elgar.

24. Skowron, B., and Milewska, E. (2018). Use of IT technologies in the management of production process quality - a case study. In: F. Bylok, A. Albrychiewicz-Słocińska, and L. Cichobłaziński (Eds.), Book of proceedings - IcoM 2018 (pp. 575-579).

25. Smółka, P. (2008). Kompetencje społeczne. Metody pomiaru i doskonalenia umiejętności interpersonalnych. Kraków: Oficyna Wolters Kluwer Business.

26. Spencer, L.M., and Spencer, S.M. (1993). Competence at work: Models for superior performance. New York: John Wiley \& Sons, Inc.

27. Whiddett, S., and Hollyford, S. (2003). Modele kompetencji w zarządzaniu zasobami ludzkimi. Kraków: Oficyna Ekonomiczna. 